\section{Administrative Problems}

The paper on administrative problems by Miss Barton discusses at some length centralized versus decentralized or subject departmentalized service. Summarizing, enlarging on, and adding to some of Miss Barton's statements, it would seem that centralized service in small and mediumsized public libraries, college libraries, school libraries, and special libraries should be maintained, whereas the large public libraries, university libraries, and reference libraries require subject departmentalized service. The budgets of smaller libraries are not adequate to maintain the personnel and books needed for an enlarged reference service. Here, also, reference work is largely localized and less complicated. In the large public libraries and university libraries a very diversified demand is made on the reference service. Literature specialists rather than subject specialists are much needed, however. Departmentalization should not be extremethat is, social science rather than economics, pure science rather than physics, etc. If the larger libraries would centralize reference service as a whole to the same location-that is, all on the same floor of the building; and if all patrons were first directed to a general reference room where the simpler fact-finding questions might be quickly disposed of and from there directed to the social science reference room, the pure science reference room, the applied science reference room, the humanities reference room, etc., where questions or problems requiring search might have the assistance of literature specialists, better reference service would result. The addition of literature specialists could be entirely dependent on the locale of the library. If there are constant demands in the field of chemistry, add a chemistry literature specialist; if history, a history literature specialist; etc. The larger library, with this type of organization, would certainly be able to supply all available data contained in its collection on any subject to its clientele promptly and efficiently.

In addition to the papers on reference work in various types of libraries and administrative problems, there is a group of papers on special reference problems in art and music, map collections, social science, science and technology, rare books, and supplementary reference materials. Mr. Angle's paper on reference work in the rare book room is brief, concise, and to the point. Mr. Kuhlman's paper on "Supplementary Reference Materials" shows clearly the complications involved in dealing with fugitive materials. A paper on public documents reference problems would have added materially to the collection.

Reference Function of the Library will bear careful reading, study, and discussion. The amazing thing is that, after over half a century of technical library training, many of the problems which faced librarians fifty years ago still remain unsolved.-Jerome K. Wilcox, University of California Library, Berkeley.

\section{The Chicago Public Library: Origins and}

Backgrounds. Gwladys Spencer. University of Chicago Press, 1943.

This study of the Chicago Public Library confines itself largely to origins and backgrounds. Some, but relatively slight, attention is given to the organization period following legislative authorization and none to the library's development.

The cultural and economic background of the city of Chicago from its founding to the establishment of the Chicago Public 
Library is fully presented. In great detail are described Chicago's early libraries and library associations, special and private libraries, and those owned by individuals. Wherever possible biographical details as to the men concerned are furnished. Books and periodicals read during these early years, book selling and book publishing, and intellectual interests of all kinds are part of the picture.

The story of Chicago's rise as a commercial and industrial center is amazing. The rapid accumulation of wealth made a flourishing of the arts possible. Miss Spencer rightly discerns that this was least creditable in the field of literature and makes no unreasonable claims for Chicago in respect to book authorship, publishing, or selling. In fact it was far behind Cincinnati in this respect for the period covered.

Three chapters tell the library story for Illinois. Again beginnings and background are emphasized. This account likewise ends with about 1872 . Legislative history is discussed in detail. $\mathrm{Li}$ braries in colleges and schools are included as well as public libraries.

Such local and regional studies of library development are welcome. It is to be hoped that others will follow. We are not sure, however, that they need go into equal detail as to all of the varied and tiny and often short-lived efforts. Miss Spencer's account seems to invest them with an importance and an influence which seems disproportionate, on the basis of current evaluation or on that of their effect on library development in Chicago and in Illinois.

An immense amount of investigation of source material and especially of contemporary records has evidently gone into the preparation of this study. We have at times, however, the feeling that the accumulated mass of material got out of hand and that the real meaning of her statistics sometimes escaped her. These criticisms apply chiefly to the chapter on economic and cultural backgrounds.

\section{Census Figures Inadequate}

The author discusses with great seriousness U.S. Census figures on illiteracy for I 840 and I850. At no time were specific tests of ability to read or write used in enumeration, and variations in accuracy and interpretation as between individual census enumerators and as between supervisors for various states and cities were inevitable. As clearly brought out by Jensen in his article, "Illiteracy" in the Dictionary of American History, this subject is difficult in the extreme.

When we read, on page $2 \mathrm{I}$, that in 1840 in Chicago "every person over twenty could read and write," our reaction is that maybe this is a "statistic" but certainly it is not a fact. We looked up Miss Spencer's authority, namely the U.S. Census Report for I840, and found that in that year in Cleveland, and in Milwaukee also, every person over twenty could read and write. We don't believe this either. We do not object to this reference to census figures of 1840 but rather to the uncritical acceptance and to resulting assumptions. Real ability to read and write a hundred years ago was by no means Ioo per cent. Present U.S. Army figures as to functional illiteracy are both more realistic and less flattering to ourselves.

On this page likewise we are informed that in 1870 "about 35 of each 1000 ... were to be considered illiterate," or 3.5 per cent, while a footnote to this para- 
graph places Chicago's illiteracy for the same year at 0.262 per cent.

The ratio of men to women in the population is also gone into extensively. This is important background information, but the situation was not peculiar to Chicago but was paralleled in other Northern pioneer communities of the period. By I 870 Chicago did not differ materially in this respect from the national average, while newer communities like St. Paul or Kansas City still had disproportionately large masculine populations.

On page 17 we find two obvious inaccuracies. "The total valuation give [sic] in 1850 was $\$ 20,000,000$. By 1870 this had grown to $\$ 377,000,000$. Thus in two decades it had increased at an average rate of somewhat over $\$ 51,000,000$ annually." We figure the rate at less than $\$ 18$,ooo, ooo annually.

The following paragraph states "The day preceding the Great Fire, nearly $250,000,000$ bushels of wheat . . . had come to the huge grain elevators and storehouses." This reported one day's receipts is more than the total annual crop of spring and winter wheat for the entire country for the year 1871. The daily capacity of flour and gristmills of Illinois in 1870 was 321,533 bushels (U.S. Census figures) or about one eighth of I per cent of this reported one day's receipts of wheat in Chicago. On page 42, item 19 reports for Chicago "An annual receipt of produce and materials of all kinds amounting to $\$ 182,743,598$." At seventyfive cents a bushel the wheat receipts reported for one day would exceed this total annual amount. It is difficult to understand how such glaring discrepancies passed not only the author but also editor and proofreader. The appearance of scholarship seems at times of greater concern than its actuality.

\section{Excessive Citations}

The number of citations seemed to us excessive and we became lost at times amidst the "op. cits." and the "ibids." On pages 59 and 60 , discussing the history of the Young Men's Association, there are eight citations to the short annual report for the year 1855 . Often it is necessary to work back through a chain of these to the first mention of the newspaper or report referred to.

Chapter XIII is devoted substantially to the first year of the newly-established Chicago Public Library. In its twentyseven pages, The Proceedings, 1872-81, of the Board of Directors are referred to thirty-one times and The First Annual Report, 1873, seventeen times. It would seem that a general reference to these brief documents might have sufficed.

Likewise we are surprised at the number of printer's errors, grammatical lapses, and cumbersome and often unclear sentences with an excessive use of adjectives. There is also much repetition, on the order of the clergyman who first told what he was going to say, then said it, and finally summed up what he had said.

Space is lacking in this review to make a convincing justification of the above assertions. To give only a few specific instances would seem picayunish, but we did in fact note a quite considerable number of instances of printer's errors, doubtful grammar, inaccurate or unclear statements, and of sentences awkward and overloaded with words.

A long bibliography is appended. We made no attempt to check it for omission or inclusion but did note the absence of two items of interest in connection with 
Newberry and his benefactions. These are the charming Diary of Julia Rosa Newberry, published r933 but covering a few years before and after the fire, and "An Early 'Friend' of Libraries" by George B. Utley, published in The Library Quarterly, July 1942, and available in reprint form. The "friend" is Mark Skinner with twenty entries in the index of the volume under review.

We have been unduly severe, perhaps, in pointing out these blemishes. Serious blemishes they are, but after all they are only blemishes on a study which is a real contribution to our understanding of the culture of our early Middle Western states and more specifically a history of library development in an important and typical state of this region. Librarianship has often been criticized, and rightly so, for its failure to create a scholarly literature. Happily the criticism is beginning to lose force. But, for this very reason, it is important that all who aspire to aid in this process should meet, in the highest degree, the high requirements for genuine scholarly writing. This requires accuracy, common sense, imagination, breadth of view, clarity, and conciseness. Industry, though essential, is a subordinate virtue.

A work of scholarship must necessarily be judged, if judged at all, on such a basis. While we regret to have found much to criticize adversely, we do want in conclusion to express to Miss Spencer the thanks of the many who are interested in the beginnings and the development of things literary and cultural for bringing together so many widely-scattered and deeplyburied facts and presenting them in so well organized a manner. We hope that other cities and regions may have the benefit of like study and research following in the pioneer footsteps of Miss Spencer and will find an historian as conscientious and interested.-Carl Vitz, Minneapolis Public Library.

\section{American Standard Reference Data and} Arrangement of Periodicals; Approved June 7, 1943. American Standards Association, 29 W. 39th St., New York. $4 \mathrm{p}$.

The first edition of this code appeared in 1935 as the American Recommended Practice, Reference Data for Periodicals, after having been approved by a general conference of publishers and librarians organized under the procedure of the American Standards Association. Work on the revision was started in 1940 by the A.S.A. Committee on Standardization in the Field of Library Work and Documentation, under the sponsorship of the American Library Association, with a committee representing fifteen library and publishers' associations.

The new code is about twice the size of the original. The rules have been expanded to greater detail and provide the solution for many more special problems. It is a manual for the person who gets out the periodical and it aims to note systematically the more or less mechanical details (usually taken care of by the managing editor) which make for the efficient handling of periodicals by all who use them or make them available for the use of others. These are such details as how to take care of volume numbers, issue numbers and date, title pages, contents, index, information which should be given under the masthead, errata slips, changes of policy, changes of title, mergers, suspensions, etc. The section on supplements of various kinds and one on society publications are entirely new. 